\title{
A NETWORK UTILIZATION PERSPECTIVE ON THE LEADERSHIP ADVANCEMENT OF MINORITIES
}

\author{
ABSTRACT \\ Social network researchers have shown that, compared to majority employees, \\ structural constraints can cause minority employees to end up in network positions that limit \\ their access to resources (i.e., social capital), and consequently limit their access to \\ professional opportunities. These findings, however, do not explain why structurally \\ equivalent minority and majority employees achieve differential returns of social capital on \\ their leadership advancement. We propose that majority and minority employees differ in \\ terms of network utilization, which is the extent to which individuals utilize their existing \\ network ties. We theorize why and how network utilization processes - career and work \\ utilization of network ties — can explain employees' (i.e., actors) influence on their leadership \\ advancement. We also explicate the process through which actors' direct and indirect \\ network connections (i.e., alters) contribute to such outcomes through both career-supporting \\ utilization and work-supporting utilization with actors. We conclude by outlining the \\ boundary conditions of network utilization theory, a theory that changes the current \\ understanding of how existing social network ties can perpetuate the underrepresentation of \\ minorities in leadership positions. \\ Keywords: social categorization; careers; social networks; actor-network theory.
}



Social network theorists have argued that members of minority groups face greater structural constraints that limit their leadership advancement (i.e., promotion to positions of leadership, Ibarra, 1993; Ng, Eby, Sorensen, \& Feldman, 2005) than members of majority groups. Minorities tend to occupy network positions lower in social capital, such that the quantity and quality of resources available in their networks — based on their structural positions within their respective networks (Kilduff \& Tsai, 2003) — is lower than that of their majority counterparts (Mehra, Kilduff, \& Brass, 1998; Konrad, Seidel, Lo, Bhardwaj, \& Qureshi, 2017). As a result, minority employees typically have less access to network connections that could otherwise facilitate their leadership advancement. These insights, however, do not explain why career disparities between minorities and majorities persist even after controlling for differences in social capital (e.g., James, 2000; Metz \& Tharenou, 2001;

Sagas \& Cunningham, 2006). Little is known about how social network processes beyond social network structure affect individual outcomes such as leadership advancement (cf. Ibarra, Kilduff, \& Tsai, 2005; Kilduff \& Brass, 2010; van den Brink \& Benschop, 2014). In particular, it is unclear why a minority employee with the same amount of social capital as a majority employee would not reap the same benefits from an advantageous network position. In this article we examine why and how structurally equivalent majority and minority employees experience significant disparities in leadership advancement.

To illustrate the central issue we aim to address, consider the following example: Alan, a White man who is an associate at a consulting firm, has expertise relevant to the strategic goals of the firm and receives excellent performance reviews. In addition, he maintains good relationships with his colleagues within and outside his department, among whom are several influential managers in strategic positions. When the opportunity to lead a new department arises, Alan, who is a good fit for the position, finds that his social network is a great resource in helping him attain this promotion. He seeks support from his social 
network and consequently becomes the top pick for the leadership position. Now, instead of Alan, consider Aisha, a Black woman who is also an associate at a consulting firm. In terms of expertise, performance and social network, Alan and Aisha are equal. The only difference is the social group to which they belong. Would Aisha seek support from the same social network as Alan? And if she did, would her efforts be as fruitful?

Situating our research at the intersection of social network theory, social categorization theory, and leadership categorization theory, we explore how stereotypical perceptions of leadership influence individuals' propensity to capitalize on their network ties to help themselves, or others, attain promotions to leadership positions. We posit that, whereas social capital can create access to potentially useful information and resources, having access to information and resources does not necessarily imply that an individual will actually use the available information and resources (Gulati \& Srivastava, 2014; Seibert, Kramer, \& Liden, 2001). Thus, rather than investigate the formation of network ties, we focus on the utilization of such ties — network utilization — which we define as the way in which individuals use existing ties in their network to fulfill a specific purpose.

Our research generates three important theoretical contributions. First, we highlight how network position alone is insufficient to predict the leadership advancement outcomes of minorities by integrating the current understanding of stereotypical preferences, which include expectations of what a leader looks like in terms of gender (i.e., that a leader is male; Schein, 1973, 1975; Lanaj \& Hollenbeck, 2015; Koenig, Eagly, Mitchell, \& Ristikari, 2011) and race (i.e., that a leader is White; e.g., Hernandez, Avery, Tonidandel, Hebl, Smith, \& McKay, 2016; Ospina \& Foldy, 2009; Rosette, Leonardelli, \& Philips, 2008). Second, our theory explains why and how existing network connections are utilized to affect minorities' leadership advancement — from the perspective of the individual aspiring to advance as a leader (i.e., the actor), and his or her social network connections (i.e., the alters). In particular, 
we propose that network utilization can serve career opportunity-related (i.e., career utilization), or work task-related (i.e., work utilization) aims, with the former being more strongly related to leadership advancement than the latter. Third, we examine how alters' network utilization with actors can also influence actors' leadership advancement. More specifically, alters can influence actors' leadership advancement depending on the alter's perception of the appropriateness of the actor's leadership advancement (i.e., careersupporting utilization) and the degree to which the alter expects the actor to make substantive work contributions (i.e., work-supporting utilization). In so doing, we not only provide new insights into the perennial problem organizations face regarding the lack of minorities in leadership positions, but also explicate the role alters have in influencing the success of minority leadership advancement. Finally, from a practical perspective, our research informs the organizational strategies that managers can employ to combat stereotype-based biases in leadership advancement outcomes.

\section{THEORETICAL FOUNDATIONS}

Our theory of network utilization draws on three theoretical perspectives: social network theory, social categorization theory, and leadership categorization theory. These areas are the orienting points that inform our research questions and guide our theory development. We detail each in turn.

\section{Social Network Theory}

A study of how individuals utilize their existing network ties begins with an understanding of social networks. Social network theory describes how entities-here, individuals - are embedded in a larger structure of relationships. The position that an individual occupies in this structure subsequently affects important individual-level outcomes, such as performance (Mehra, Kilduff, \& Brass, 2001; Fang, Landis, Zhang, Anderson, Shaw, \& Kilduff, 2015), influence (Sparrowe \& Liden, 2005; Bowler, 
1

2

3

4

5

6

8

Halbesleben, Stodnick, Seevers, \& Little, 2009), and promotions (Brass, 1984; Burt, 1992; Adler \& Kwon, 2002; Seibert, Kramer, \& Liden, 2001; Feldman \& Ng, 2007). The most beneficial strategic positions are those that are central in the social network, have diverse and influential social network connections, and bridge disconnected clusters of individuals - i.e., have high levels of social capital (Kilduff \& Tsai, 2003). These ties to diverse and influential individuals provide access to resources that contribute to individual-level outcomes, for instance, by offering unique information or providing support.

Social network theorists have adopted a structural determinism perspective in which actors in advantageous network positions presumably possess the skills, abilities, and motivations to make optimal use of the resources in their network. In contrast, disadvantageously positioned actors are assumed to lack the skills, abilities, and motivation to overcome structural constraints (Kilduff \& Brass, 2010). This deterministic perspective has been criticized for failing to acknowledge agency (i.e., individuals' autonomous actions), a criticism which highlights the need for the field of social networks to develop rich psychological theory at the intersection of agency and structure (e.g., Ibarra, Kilduff, \& Tsai, 2005; Kilduff \& Brass, 2010; van den Brink \& Benschop, 2014).

Although psychological dynamics have not been entirely absent from social networks research, they are often described as structural processes that determine the formation of networks. For instance, homophily—based on Byrne's (1971) similarity/attraction paradigm — explicates the process by which individuals who are more similar are more likely to form connections (McPherson, Smith-Lovin, \& Cook, 2001). Because organizational networks, and especially networks of power and influence, are dominated by individuals belonging to the social category of White men, homophily-based processes explain why it is more difficult for members of other social categories to attain influential network positions with high levels of social capital (Ibarra, 1993; Mehra et al., 1998; Konrad et al., 2017). 
Whereas this explanation is compelling in terms of explaining the development of social networks, it remains silent about potential differences in individuals' utilization of their existing networks (cf. Burt, 1992; cf. Kilduff \& Brass, 2010).

The first step of introducing an agency perspective to social networks theory is to understand how individuals decide to realize potential opportunities in their network. A purely determinist perspective would equate structural position to an individual's skills, abilities, and motivation to optimally use the resources available in the network. Such a perspective would imply—incorrectly — that minorities, who are more likely to reside in peripheries of social networks (as compared to majorities), lack the skills, abilities, and motivation to optimally use the resources in their network (cf. Kilduff \& Brass, 2010). Therefore, it is important to separate the decision to engage in network utilization based on opportunity (i.e., structure) from agency. In effect, "entrepreneurial opportunity and motivation" (Burt, 1992, p. 35) have been thought to derive solely from structural position. In contrast to this view, we theorize that processes resulting from the social category to which individuals belong can account for differences in actors' utilization of network resources.

This is not to deny differences in network positions between minority and majority members. We know majority members tend to have more advantageous network positions than minority members, and we know homophily accounts for such structural differences. Rather, the point that needs to be addressed is that even when minorities and majorities occupy structurally equivalent positions, when it comes to leadership advancement, majorities benefit more from their position than minorities. Thus, the starting point of our analysis is a situation of structural equivalence (Burt, 1987)—minorities and majorities occupying similar network positions - not because this is typically the case (because it is not), but because this allows us to address the problem at hand: the disparity between minorities and majorities in leadership advancement, even when occupying structurally 
equivalent network positions.

Importantly, we assume that the network is dominated by the majority-both in the sense that most individuals in the network are majority members, and in the sense that the majority is overrepresented in higher hierarchical positions (US Census, 2016). This assumption is consistent with the original, numerical definition of minority and majority (Blau, 1977). With this assumption in place, we focus on the mechanisms through which disparities in leadership advancement arise over and above the social network's structural features and constraints. We reason that individuals' decisions to utilize their network ties can be influenced by socially constructed perceptions (cf. Gilovich, Griffin, \& Kahneman, 2002). To explain how individual agency is subject to these socially constructed perceptions in network utilization for leadership advancement, we draw from social categorization and leadership categorization theories.

\section{Social Categorization Theory}

Social categorization is a fundamental human perceptual process that helps individuals reduce and summarize information by grouping people based on similarities and differences (Turner, Hogg, Oakes, Reicher, \& Wetherell, 1987; cf. Rosch, 1978). Members of a given category share similarities that differentiate them from members of other categories.

Categorizations are highly informational and readily activated (i.e., salient) when they capture similarities and differences between people (e.g., when the focus is on physiological differences, a gender categorization may be informative). By implication, the more a categorization captures similarities and differences between people, the more likely it is to be salient.

Social categorizations give rise to stereotypes, which are generalized beliefs about specific characteristics that are associated with a social group (Judd \& Park, 1993). These stereotypes are readily, often subconsciously, used by individuals and broadly applied to all 
members of a particular social category. Different minority social groups are associated with different stereotypes, which can vary in terms of content, for instance, with regard to social status (Berger, Rosenholtz, \& Zelditch, 1980; Johnson, Freeman, \& Pauker, 2012), competence (Fiske, Cuddy, Glick, \& Xu, 2002; Sanchez-Hucles \& Davis, 2010), and agency (Bem, 1981; Carton \& Rosette, 2011). A Black woman might be at a disadvantage relative to a Black man in terms of social status (Rosette \& Livingston, 2012) because of the communal, submissive stereotypes associated with women in addition to the stereotype of incompetence associated with being Black (Carton \& Rosette, 2011) —unless she is agentic (Livingston, Rosette, \& Washington, 2012). Indeed, stereotypes associated with a minority member's social category are multifaceted and can intersect in distinct ways to influence perceptions (Kang \& Bodenhausen, 2015).

Since the impetus for our analysis lies in the leadership advancement challenges experienced by gender and racial minorities in the workplace, we examine minority categories associated with stereotypes of lower competence as compared to White men. This approach is consistent with our earlier discussion of social network theory. Assuming the network is dominated by the majority (i.e., White men) — both numerically and in terms of their overrepresentation in higher hierarchical positions - we focus on how minority

categories give rise to stereotypes about competence, which can reinforce their lower position compared to the majority.

Next, we describe how social categorization processes influence the perception of fit between an actor's characteristics and a leadership position (cf. Peters, Ryan, Haslam, \& Fernandes, 2012). We explain why stereotypes that are associated with the White male category have greater overlap with implicit theories about what good leadership entails than stereotypes associated with minority groups.

\section{Leadership Categorization Theory}


Individuals often — consciously or subconsciously_distinguish leaders from nonleaders using their implicit leadership theories, or cognitive representations of leader categories. These leader categories are shaped by individuals' past interactions and personal experiences (Fiske \& Taylor, 1984; Reskin \& Ross, 1995; Foti, Knee, \& Backert, 2008). Based on these implicit leadership theories, a pattern matching process (Lord, Foti, \& Phillips, 1982) is employed to compare an individual's characteristics to those of a prototype (i.e., cognitive representation) of the relevant leader category to determine whether that individual matches the profile of a leader. In addition, individuals engage in a pattern completion process once they perceive an initial match between an individual and the leader prototype (Shondrick, Dinh, \& Lord, 2010), such that prototypical traits and behaviors are associated with the categorized individual — whether or not they have exhibited these prototypical traits and behaviors.

Because leader prototypes are based on individuals' past experiences with leaders, some variation in the content of these leader categories has been found (e.g., depending on an individual's culture [Gerstner \& Day, 1994] and gender [Schein, 2001; Vial, Brescoll, Napier, Dovidio, \& Tyler, 2018]). Generally, however, there is a great deal of overlap in individuals' cognitive leader representations (Epitropaki \& Martin, 2004; Lord et al., 1984;

Shondrick et al., 2010). A key finding from the perspective of the current analysis is that demographic characteristics are associated with the leader prototype, such that leader prototypes are typically male (Schein, 1973, 1975; Koenig et al., 2011) and White (Rosette et al., 2008).

Such implicit leadership theories (Eden \& Leviatan, 1975) perpetuate biased preferences for leaders based on gender and race. Factual attributes (i.e., men are overrepresented in leadership positions, Zweigenhaft, 2014; US Census, 2016) are instrumental in developing gendered perceptions of leadership, and such perceptions of 
leadership are instrumental in perpetuating the disproportionate number of men in leadership positions (Eagly \& Carli, 2007a; 2007b). This mechanism can similarly shape racial perceptions of leadership (Chung-Herrera \& Lankau, 2005; Liu \& Baker, 2016; Nkomo, 1992; Rosette \& Livingston, 2012), fusing the leadership category with the White male category (cf. Heilman, 1983, 2001).

As a result, White men are more readily perceived as leaders and are more likely to be expected to succeed in leadership positions (Burgess \& Borgida, 1999; Eagly \& Karau, 2002; Lyness \& Heilman, 2006; Rosette et al., 2008). The perceived fit between their social category and the leader category enhances their advancement to positions of leadership (cf. Burgess \& Borgida, 1999; Lyness \& Heilman, 2006; Rudman \& Phelan, 2010). The pattern completion process that individuals engage in after perceiving initial fit reinforces

perceptions of fit and increases confidence in a leader's success. Conversely, perceived incongruence between an individual's demographic characteristics and the characteristics that are associated with the leader prototype can prompt perceptions of misfit between the individual's social category and leadership potential, and reduce confidence in his or her ability to succeed as a leader. As such, implicit associations about leadership are incongruent with social category-based perceptions of minority groups.

To understand how network utilization can affect the underrepresentation of minorities in leadership positions, it is important to distinguish it from related constructs and processes. Having laid this theoretical groundwork, we discuss the conceptual distinctiveness of network utilization before developing our conceptual model of how network utilization differentially affects the leadership advancement of majority and minority groups.

\section{CONCEPTUAL DISTINCTIVENESS}

Network utilization is theoretically and conceptually distinct from network creation and types of network ties. Unlike network creation (i.e., the formation of new network ties), 

network utilization captures the way in which individuals make use of the available information and resources in their social networks. That is, rather than focusing on the constraints minorities face in attaining high levels of social capital through the creation of network ties (cf. Ibarra, 1993; Mehra et al., 1998), we focus on the utilization of their existing ties. Network utilization can be enacted by an actor (i.e., an individual utilizing their social network connections [ties] to achieve a certain outcome), as well as by alters (i.e., alters utilizing their connection [tie] to an actor to achieve a certain outcome). Existing network connections can offer leadership advancement opportunities to individuals within the network. However, the extent to and ways in which actors and alters capitalize on these opportunities can differ in meaningful ways.

Moreover, instead of focusing on the type of network ties utilized within a network, we focus on why individuals draw from their social ties. Indeed, although social network researchers have identified conceptually distinct ties (e.g., information exchange, advice seeking and giving, and friendship, Borgatti et al., 2009), in practice, these ties are highly correlated (Borgatti \& Foster, 2003) and provide functionally equivalent potential value to an actor's leadership advancement. Any organizational network connection-be it a colleague, friend, or superior - is a potential resource to an actor's leadership advancement. Myriad ties can provide insight into job openings, offer advice on how to overcome potential hurdles, provide expertise to improve task outcomes, or serve as a link to a colleague with valuable information or to an important skip-level manager.

Network utilization describes the interactive process between individual agency and the network. Scholars have empirically demonstrated that individuals differ in the extent to which they can benefit from opportune structures around them, in part, based on their individual characteristics (e.g., Baer, 2010; Zhou, Shin, Brass, Choi, \& Zhang, 2009). For instance, Baer (2010) found that individuals who are more open to experience benefit more 
from an advantageous network position in terms of individual creative output. In formulating a conceptual model of network utilization, we elaborate on why existing ties are used for different purposes by actors based on gender and racial characteristics, and how alters' career- and work-supporting activities can produce opportunities for actors to assume positions of leadership.

\section{CONCEPTUAL MODEL}

Actors and alters will consider the possible payoffs of utilizing their existing network ties for different purposes based on social categorization processes, as well as the potential risks of backlash from these different forms of utilization. Indeed, "people are likely to weigh their preferences according to [...] perceptions [of job opportunities] to not waste time pursuing "poor bets"” (Gottfredson, 1981: 570). In other words, individuals will balance

trying to achieve their desires with their sense of what is attainable. Thus, social categorization based on perceived fit with stereotypical expectations can determine both actors' utilization of network ties and alters' network utilization with an actor.

Scholars have asserted that individuals who aspire toward leadership advancement should be well positioned within the organizational network to identify and receive career opportunities, as well as demonstrate strong performance (Burt, 1992; Ng et al., 2006).

Therefore, we begin by distinguishing two specific purposes - career and work utilization of network ties — that describe actors' reasons for utilizing their network. Notably, these purposes are not mutually exclusive; a tie can be perceived as valuable for both career and work purposes. We then broaden our focus from the actor's perspective to alters' role in network utilization processes. As shown in Figure 1, each alter in an actor's network can provide unique contributions to an actor's leadership advancement through career-supporting utilization by leveraging relationships in the form of referrals (e.g., Podolny \& Baron, 1997 ; Seibert et al., 2001) or through work-supporting utilization by drawing on the actor's 
perceived task-based competence (e.g., Sparrowe, Liden, Wayne, \& Kraimer, 2001).

--- Insert Figure 1 about here ---

\section{Network Utilization}

Career Utilization. We define career utilization of network ties as the actions an actor takes to engage his or her network ties with the purpose of improving his or her career opportunities. Examples of career utilization include informing an alter of the actor's promotion aspirations, asking alters to keep an eye out for career opportunities that might be suitable for the actor, requesting career advice, references or introductions from alters, and maintaining relationships with alters that could help the actor's career. An alter who is aware of an actor's career ambitions is more likely to share information about career opportunities with that actor, to endorse the actor for various career opportunities, or even to offer the actor a promotion, assuming there is no competition between the actor and the alter. If actors do not discuss their career ambitions with alters, career opportunities might reach them later, too late, or not at all.

The exchange of information between actors and alters not only serves to signal actors' leadership advancement wishes, but also prompts alters to interpret the actors' behaviors as intentions to increase their chances at future job opportunities. Within this ongoing exchange, actors engage in career utilization of network ties so that they can receive and act upon alters' information. In so doing, they also communicate the expectation of returning the favor to alters once in positions of leadership (cf. the norm of reciprocity in social interaction; Gouldner, 1960), creating a self-perpetuating cycle of career ascension. Actors' career utilization of the network is thus directly and positively related to their leadership advancement.

We propose that majority and minority actors differ in their perceptions of the usefulness, legitimacy, and expected success of career utilization. Actors assess the 
usefulness of their network for career purposes by evaluating which alters in their social network have the influence to improve their leadership advancement outcomes. This assessment is based on social network structure (i.e., identifying the influential individuals within their network), and social categorization processes (i.e., congruence between an alter's social category and the actor's social category). Structurally equivalent majority and minority actors will not differ in the extent to which they identify influential individuals within their networks. However, similarity between an actor and an alter is associated with higher levels of support, and subsequently influences actors' perceptions of the usefulness of their network ties (Ibarra, 1995). As such, majority actors will perceive their networks as being more useful for career purposes as compared to minority actors because influential alters are more likely similar to the majority social category, i.e., White, male. In contrast, minority actors might perceive the same network as less useful to them because of greater incongruence between their and the influential alters' social categories.

Furthermore, an actor's perception of how legitimate it is to engage in career utilization is associated with his or her confidence in succeeding in the leadership endeavor. The assessment of legitimacy involves the congruence between the actor's social category and the leader category, as well as the alignment of these categories with the existing social status hierarchy. In majority-dominated social networks, minority actors' perceived incongruence with a leader role can trigger feelings of stereotype threat (Steele \& Aronson, 1995; Spencer, Steele, \& Quinn, 1999; Burnette, Pollack, \& Hoyt, 2010), and can lead to them questioning their own legitimacy in striving for leadership advancement. Stereotypethreatened individuals are reluctant to take on roles that are not consistent with the stereotype that is attached to their social category (Keller \& Dauenheimer, 2003), and often actively avoid such roles altogether (Davies, Spencer, \& Steele, 2005).

Actors' decisions to engage in career utilization can also hinge on how they expect 
individuals in their networks to respond to their career utilization. Minorities might feel uncomfortable utilizing their network for career purposes because engaging in career utilization — communicating with their network that, contrary to stereotypical expectations, a leadership position would be a good fit for them — defies the existing social status hierarchy (Berger et al., 1980; Sidanius \& Pratto, 2001; Mendes, Blascovich, Hunter, Lickel, \& Jost, 2007), and thus, might result in a rejection that damages their reputation. Although minorities might have more reason than majorities to want to change the social status hierarchy, they are also more likely to experience social sanctions for behaving in ways that are inconsistent with the stereotype-based expectations associated with their social groups (e.g., gender effects, Burt, 1997, 1998; Parks-Stamm, Heilman, \& Hearns, 2008). When supported by alters who also challenge the status hierarchy, minority actors might become more comfortable using their networks for career-related purposes. Thus, the social category to which an alter belongs is an important factor in actors' expectations of the success of their career utilization. Additionally, actors' expectations about their network's implicit leadership theories can shape their expectations about how appropriate their career utilization will be perceived by their network. Stronger representation of similar others in positions of leadership will reduce an actor's fear of rejection by the network.

To summarize, even though career utilization of network ties is directly related to leadership advancement, we posit that minority actors will engage less in career utilization than majority actors due to stereotype-based expectations of alters in their network, of themselves, and of the actor-alter interaction. Given our assumption of a majority-dominated network, minority actors, as compared to majority actors, thus tend to perceive their networks as being less useful for career purposes, believe that engaging in career utilization is less

legitimate, and expect more rejection from their network when they engage in career utilization. Conversely, majority actors view their networks as more useful for career 
purposes, view engaging in career utilization as more legitimate, and are more likely to expect successful outcomes from their career utilization.

Proposition 1. Compared to majority actors, minority actors will engage in less career utilization of network ties, which contributes to minorities'lower leadership advancement.

Work Utilization. Work utilization of network ties refers to the actions an actor takes to engage his or her network ties with the purpose of improving his or her task performance. Engaging in work utilization includes requesting a direct alter to provide input in terms of information, technical help, and idea generation (Borgatti \& Cross, 2003; Joshi \& Knight, 2015) on the actor's project. An actor's work utilization of network ties has the potential to improve that actor's performance because it allows for the integration of multiple

perspectives into the actor's task (Joshi, Liao, \& Jackson, 2006), and gives an actor more insight into the requirements of the task output. In addition, work utilization can improve the visibility of the actor's knowledge, skills, and abilities among network connections. Although work utilization might not translate into leadership advancement in the short term, over time, network connections could turn to the actor for expertise-related opportunities.

Like the decision to engage in career utilization, an actor's decision to engage in work utilization is driven by perceptions of usefulness, legitimacy, and expectations of success. Unlike our predictions about minority/majority differences in career utilization, we propose that majority and minority actors will not differ in their perceptions of how useful and how legitimate engaging in work utilization can be, but will differ in their expectations of the positive outcomes of work utilization.

We theorize that to assess the usefulness of a social network for task improvement, actors take into account both social network and social category factors: they identify the expertise present in the network and consider the social status of alters as defined by their 
social category. The requirements of the actor's job are compared to the ways in which alters surrounding the actor can contribute to improving the actor's job performance. The decision with whom to engage in work utilization is thus partly based upon what alters might add, which is a structural factor that does not covary with the demographic characteristics of the actor, assuming structural equivalence. A minority actor's network offers the same resources

as a structurally equivalent majority actor's network, so minority and majority actors wanting to improve their task performance will perceive their networks as offering equivalent potential task contributions (Ibarra, 1995).

Furthermore, because engaging in work utilization would not defy the existing social status hierarchy for minority actors, minority actors might feel less constrained about utilizing their ties for work purposes. The legitimacy of utilizing ties for work purposes is often included in job descriptions, for instance, in the expectation to collaborate with colleagues as part of the job requirements - particularly when teamwork is an important feature of the job. Thus, minority and majority actors will likely perceive similar levels of legitimacy regarding their decisions to engage in work utilization.

Expectations about realizing successful outcomes from engaging in work utilization, however, can differ between minorities and majorities. Based on social categorization, minority actors might hesitate to engage in work utilization when it takes the form of seeking help from their network connections because such actions could affirm stereotypes of low competence (Berger et al., 1980; Lee, 1997; Tessler \& Schwartz, 1972; Brooks, Gino, \& Schweitzer, 2015). That is, minority actors who reach out for task-based help might be perceived as underperformers or less knowledgeable and thus, thought to be less able to reciprocate with expertise or task-based advice. Because individuals typically use their connections to maintain a fair, reciprocal exchange (Gouldner, 1960), this perception that minorities will not be able to reciprocate might curtail their chances of leadership 
advancement within the organizational context unless proactively managed over time. This danger is especially acute for minority newcomers who have yet to form close working relationships with alters (Morrison, 2002). In contrast, majority actors are unlikely to believe that work utilization will affirm their incompetence because this is not a characteristic linked to the majority stereotype, and thus cannot be affirmed with actions performed by the

majority actor.

Proposition 2. Compared to majority actors, minority actors will engage in less work utilization of network ties, which contributes to minorities' lower leadership advancement.

\section{Differential effects of career and work utilization on leadership advancement.}

We posit that work utilization is generally a less effective activity in generating

leadership advancement outcomes than career utilization for both minority and majority actors. Although work utilization can improve current job performance, it may not influence alters' assessments of an actor's future job performance if a potential future job requires a different skill set. A leadership role is associated with different requirements (cf. Borman \& Motowidlo, 1997) and stereotypes (cf. Sy, 2010) than a non-leader role. Thus, even though an actor might have high in-role performance, which correlates with leadership advancement

(Ng et al., 2005), the actor's performance will not necessarily translate into the expectation that he or she will perform well in a role that requires a different set of skills.

Moreover, when actors engage in work utilization, minority (as compared to majority) actors are likely to benefit less, especially when opportunities involve some kind of leadership. A minority actor who has demonstrated expertise on a different set of skills might still be passed over. The reason for this differential effect is that minority actors who seek to advance beyond specific skill-based tracks are subjected to more stringent competency standards, as compared to majority actors (Foschi, 2000). Minorities generally need to 
demonstrate more work experience, more job-specific experience, and longer tenure before being promoted (Smith, 2005).

Take for instance the case of Hooria, who is not considered to lead her department's new interdisciplinary project, despite having has a reputation for being an expert in statistics and for always delivering high quality work. Her capabilities as a statistician do not automatically spill over to competence judgments in other domains, such as leadership. The social category to which she belongs forms a misfit with the leadership category such that she is not perceived as possessing the requisite leadership qualities — despite defying the expectations of the social category she belongs to with regard to her statistical abilities. This example illustrates what scholars have shown: as compared to men, women's professional progression to new positions tends to align closely with their previous skills-based

performance (Lyness \& Schrader, 2006). A minority actor might improve his or her job performance to become a more eligible candidate for a future job opportunity, but unless he or she communicates this to alters within the context of their ongoing work exchanges, others will be more likely to attribute the actor's work utilization simply to a desire to improve current job performance, without inferring any career ambitions beyond that.

Proposition 3a. Compared to career utilization of network ties, work utilization of network ties is less effective in producing leadership advancement, especially for minority actors.

Not only is career utilization more strongly related to leadership advancement than work utilization, but we also expect that the difference between minority and majority actors' career utilization, as described in Proposition 1, to be larger than the difference in work utilization, as described in Proposition 2. This implies that minority actors suffer a "double disadvantage" when it comes to leadership advancement: Lower levels of career utilization are more detrimental to leadership advancement than lower levels of work utilization, and it 

is precisely on career utilization that minority and majority actors differ most.

We reason that in assessing the usefulness, legitimacy, and expected success of career utilization, implicit leadership theories play a more prominent role than in assessments related to work utilization. Because career utilization has a stronger positive effect on leadership advancement than work utilization, and because differences in career utilization

between minorities and majorities are larger than in work utilization, career utilization is likely to create a more significant barrier to leadership advancement for minorities, as compared to majorities. Thus, minority (as compared to majority) actors' lower career utilization creates more unfavorable leadership advancement outcomes than differences in work utilization. Figure 1 depicts the relationships between an actor's career and work utilization and leadership advancement. We visually distinguish between the proposed magnitude of these effects by varying the weight of causal arrows, demonstrating that career utilization is at once a more influential driver of leadership advancement than work utilization, and a more consequential obstacle to leadership advancement for minority than majority actors.

Proposition 3b. The difference in career utilization between minority and majority actors is larger than the difference in work utilization, which exacerbates differences

between minority and majority actors in leadership advancement.

Thus far, we have discussed the implications of network utilization for career and work purposes by the actor. Actors, however, also have alters in their network who can wield their influence to improve actors' leadership advancement outcomes. That is, just as actors reach out to alters, these alters (i.e., superiors, peers, and subordinates) can contribute to the actor's leadership advancement through career- and work-supporting network utilization activities. Hence, we now examine how alters can facilitate actors' leadership advancement.

\section{ALTERS' NETWORK UTILIZATION}



Social categorization processes apply not only to actors' utilization of network ties, but also to alters' willingness to engage in network utilization with actors. Both peer-level alters and alters who are higher in the hierarchy can engage in network utilization with an actor. Nevertheless, a hierarchically more powerful alter with job-assigning authority would be expected to have a greater influence on an actor's leadership advancement (cf. Bian, 1997;

Pieper, 2015). This is because these alters are not merely information providers (which peerlevel alters are likely to be), but also influential sources when it comes to making decisions about promotions. Alters' network utilization with the actor can take the form of activities supporting the actor's career activities (e.g., recommending the actor for a leadership position because of his or her perceived leadership potential), and work activities (e.g., enlisting the help of an actor because of his or her task-relevant expertise). We theorize about each path and their differential effects on actors' leadership advancement.

\section{Alters' Career-Supporting Utilization}

Alters can be important sources of leadership opportunities, especially if they occupy positions with job-assigning authority (Bian, 1997). Actors who want to advance into positions of leadership usually have few direct ties to such influential alters because direct alters are more likely to occupy a similar hierarchical position in the network (Granovetter, 1992). Actors are likely indirectly connected to such influential alters, and the distance between the actor and these indirect alters may range from a close connection via a direct alter of the actor to a more distant one via several sequential alters.

Individuals who occupy a network position between two disconnected others, or "brokers," have a potentially strategic position from which they can control resource flow (e.g., information) for their own advantage (Burt, 1992). Brokers can also use their position to bring together otherwise disconnected others without necessarily deriving self-benefits (Baker \& Obstfeld, 1999). These brokers with a tertius iungens ("third who joins") 
orientation may decide to maintain coordination among newly formed connections or relinquish their coordinating activities (Obstfeld, 2005). We refer to the latter brokers as referring brokers in the following sections. An alter who has decision-making influence is often informed by referring brokers who will vouch for an actor's leadership capabilities. Referring brokers allow actors to tap into the indirect network, which provides a deep pool of potentially beneficial resources. Such resources can include influence or valuable, non-redundant information (Bian, 1997; cf. Granovetter, 1992) that can benefit actors' work performance or leadership advancement. Indeed, actors benefit more from the resources their indirect ties offer (Bian, 1997) than those offered from their direct ties. Actors are particularly likely to benefit from indirect alters who are well-positioned in the organizational hierarchy and have a reciprocal relationship with the referring broker. Influential alters can also benefit from the indirect network, as it allows them access to a larger talent pool. Thus, referring brokers play a key role in connecting an actor to an indirect alter (Pieper, 2015) by deciding to which alter they will refer an actor and vice versa.

We theorize that social categorization processes will increase referring brokers' selection of majority actors when advising influential alters who seek to advance actors into leadership positions. Consider, for instance, that a referring broker has to engage in a memory search to refer one individual to another. The human brain is incapable of activating the full set of possible ties an individual has, and instead only a certain subset of ties is recalled when an individual engages in such a memory search (Dunbar, 1992; Smith, Menon, \& Thompson, 2012). As a result, social categorization processes can shape referring brokers' memory search and selection processes to disadvantage minority actors in at least two ways: referring brokers' recall of actors is primed by implicit stereotypes, and referring brokers make referrals based on similarity in demographic attributes.

First, a referring broker who is probed by an alter to think about potential actors with 
"leader" attributes will prompt the recall of majority actors, based on their congruence with implicit stereotypes (cf. Koch, D’Mello, \& Sackett, 2015). As a result, referring brokers are more likely to engage in career supporting utilization with majority actors than with minority actors. Second, because social category primes referring brokers' memory search (cf. Feldman, 1981), the referring broker is likely to recall an actor from the same social category as the alter (and vice versa) (cf. Schneider \& Shiffrin, 1977; Shiffrin \& Schneider, 1977). A minority actor is therefore more likely to be matched with another minority, and a majority with a majority — over and above the number of minorities versus majorities in the referring broker's direct network. Referring brokers are thus less likely to refer a minority actor to a majority indirect alter. Given the dominance of majority actors in hierarchically superior positions, influential indirect alters are likely to belong to the majority category, which reduces the chances of a minority actor being connected by referring brokers. Proposition 4. Referring brokers are less likely to refer minority, as compared to majority, actors to influential indirect alters. This lack of career-supporting network utilization by alters contributes to minority actors' lower leadership advancement. Collectively, referring brokers' memory search and selection processes disadvantage minority actors because once a powerful alter offers a leadership opportunity, a referring broker is more likely to refer a majority actor than a minority actor to this alter. The referring broker is also more likely to match a majority alter to a majority actor based on social category similarity. This implies that if a minority actor requests a referral, the actor is less likely to be connected to a powerful alter because the referring brokers will have fewer powerful minority alters in their network (see Figure 2).

--- Insert Figure 2 about here ---

\section{Alters' Work-Supporting Utilization}


Alters engage in work-supporting utilization of an actor by requesting input from the actor for a specific task because the actor has expertise in an area that the task or project requires. When many alters utilize their tie to the same actor for work-related purposes, the probability for leadership advancement of the actor increases substantially as the actor's reputation for competence spreads through the organizational network. Indeed, reputation has been found to predict individuals' hierarchical position and income (Blickle, Schneider, Liu, $\&$ Ferris, 2011). Another positive outcome of a reputation for competence might be that the actor could be considered for projects that require some form of informal leadership (such as project management), which can build actors' leadership capabilities, making them more eligible for future leadership positions.

Both peer- and higher-level alters can engage in work-supporting utilization with the actor, but they are likely to differ in their influence on the actor's leadership advancement outcomes. Peer-level alters are more likely to incorporate the actor's knowledge and expertise in their own day-to-day jobs (much like how actors utilize their network for work purposes), whereas higher-level alters are more likely to engage actors in longer-term projects. Moreover, the actor's reputation for competence is more likely to grow among peer-level alters before reaching higher-level alters. Information is more likely to be exchanged between peers because they are usually more accessible than higher-level colleagues (cf. Borgatti \& Cross, 2003). This means that an actor's reputation will likely improve among the actor's peers before it does so among higher-level connections.

All other things being equal—such as the actor's network position (i.e., structural equivalence), function, or expertise - ties to a minority will be less utilized for work-related purposes by their connections than ties to a majority (McGuire, 2002). As an illustration of this phenomenon, consider the following example. Juana and John are biochemists in the same department of an engineering firm, with similar knowledge and tenure. Both have a 
special aptitude for conducting experiments. However, Juana is far more likely than John to have her methods and findings questioned. Despite their equal expertise, their colleagues do not question John's competence but they do question Juana's, in part due to prevailing stereotypes about gender and scientific competency. In support of this phenomenon, ThomasHunt and Phillips (2004) found that expert women were perceived as having less expertise than expert men. Moreover, the more expertise the women possessed, the more their teammates challenged their expertise, which translated to impaired team performance. The possession of expertise alone does not translate to a reputation for competence; one needs to be perceived as possessing expertise.

Social categorization processes detrimentally affect competency perceptions of minority actors. Leslie and colleagues (2015), for instance, attribute the underrepresentation of women and African Americans in certain academic fields to the low competence stereotype associated with these social categories (as compared to White males). Because minorities are generally viewed as less competent than majorities (cf. Berger et al., 1980; Meeker \& Weitzel-O’Neil, 1977; Fiske et al., 2002), alters are less likely to engage in worksupporting network utilization with minority (as compared to majority) actors.

Proposition 5. Compared to majority actors, alters are less likely to engage in worksupporting network utilization with minority actors, which contributes to minorities' lower leadership advancement.

Thus far, we have proposed that the leadership advancement of minorities is impeded by the social categorization processes that occur in their own and their alters' network utilization. Figure 1 depicts the relationships between alters' network utilization in terms of career-supporting utilization and work-supporting utilization, and actor leadership

advancement. Here again, we visually distinguish between the proposed magnitude of these effects by varying the weight of causal arrows, demonstrating that career-supporting 
utilization is at once a more influential driver of leadership advancement than worksupporting utilization, and a more consequential obstacle to leadership advancement for minority than majority actors.

It is important to note, however, that a core assumption in our theorizing has been that the social network is majority-dominated. That is, we assumed a social network dominated by majority group members (i.e., White men) where minority social categories give rise to low competence stereotypes, and implicit leadership theories favor White and male social categories for positions of leadership. Propositions 1 through 5 hold in majority-dominated networks such that the more the network is majority-dominated, the more robustly we would expect these relationships to exist. Nevertheless, although social categorization processes pervasively influence network utilization, social categorization-induced biases are not inevitable, especially in organizations that have network diversity at high levels of the organizational hierarchy. In the following section, we examine how a diverse pool of powerful alters can constrain the use of category-based stereotypes in the network utilization processes that drive minority leadership advancement.

\section{BOUNDARY CONDITIONS}

We began this article by delineating the tenets underlying our theory of network

utilization, derived from the theoretical foundations of social network theory, social categorization theory, and leadership categorization theory. We now examine how relaxing our core assumption of majority dominance can attenuate or enhance the conditions determined by categorization processes (i.e., implicit leadership theories that favor White men, and low competence stereotype for minorities). In particular, we analyze how network diversity can mitigate the theorized differences between minorities and majorities in leadership advancement that arise due to network utilization.

\section{Network Diversity}


A majority-dominated leadership network is an important reason why most individuals' implicit leadership theories favor White men. Because implicit leadership theories are shaped by individuals' experiences with leadership (Eden \& Leviatan, 1975), a majority-dominated network of leaders creates implicit leadership theories that align with the demographics that are associated with the majority (Lord, Foti, \& De Vader, 1984). The more White men are represented in positions of leadership, the more implicit leadership theories align with expectations of leaders being White men. Greater network diversity throughout all levels of the hierarchy can shape which characteristics employees consider prototypical for leaders, reducing the strength of alters' implicit leadership associations to White and male social categories.

Correspondingly, network diversity can increase the number of powerful minority

alters in referring brokers' networks, thereby increasing the chances of minority actors being referred to those powerful alters. Moreover, the support minority actors receive from demographically similar alters (Zatzick, Elvira, \& Cohen, 2005) can generate high quality relationships that spill over to advice giving and seeking, a prediction consistent with the principle of homophily (Ibarra, 1993, 1995). In this way, the usefulness, legitimacy, and expected outcomes of minority actors' ties for career- and work-related purposes are enhanced.

Because majority members are also more likely to subscribe to competence stereotypes than minority members (Handley, Brown, Moss-Racusin, \& Smith, 2015; Project Implicit), having more majorities in influential positions strengthens the degree to which low competence stereotypes are applied to minorities. Yet, as the representation of minorities increases across roles and functions, so do opportunities for intergroup contact (Pettigrew \& Tropp, 2006). As alters become exposed to individuating information, which often negates stereotypic beliefs (e.g., a star woman engineer; cf. Bem, 1981; Glick, Wilk, \& Perreault, 
1995; Leslie et al., 2015), their biased assumptions based on social category information (Fiske \& Neuberg, 1989; Fiske \& Neuberg, 1990; Fiske, Lin, \& Neuberg, 1999; Wood \& Karten, 1986) are diminished. Individuating information, in effect, can enhance alters' understanding of within-category variability and between-category similarity. As a result, alters' reliance on stereotypes of low competence associated with minority social categories

is reduced because individuating information overrides inaccurate stereotypes. Collectively, we posit that network diversity can mitigate differences in leadership advancement outcomes between minorities and majorities that arise due to network utilization.

Proposition 6. Increased network diversity will reduce differences between minorities and majorities in leadership advancement due to network utilization by (a) weakening implicit associations between White and male social categories and leader prototypes, (b) enhancing opportunities for intragroup support, and (c) diminishing associations between stereotypes of low competence and minority actors through individuating information.

\section{GENERAL DISCUSSION}

Our theory of network utilization explains why minorities are underrepresented in leadership positions, over and above the structural constraints they face in creating social capital. Building on theoretical insights at the intersection of social network theory, social categorization theory, and leadership categorization theory, we propose that the career and work utilization of network ties differs across minority and majority actors. Minority actors engage less than majority actors in career utilization due to lower perceptions of the usefulness of their network for career purposes, hesitations about their legitimacy with regard to engaging in career utilization, and expectations of rejection. Minority actors also engage less in work utilization out of fear of confirming stereotypical expectations of incompetence 
associated with their social category. Moreover, even when minorities engage in network utilization, their efforts are likely to create slower and less successful advancement to leadership positions. Although alters can be a highly valuable resource for an actor's leadership advancement, alters' network utilization can perpetuate their own biases in the referrals they choose to make and the individuating information needed to override their competency-based expectations of actors' social category. Taken together, our theory of network utilization has important implications for both theory and practice.

\section{Theoretical Implications}

We have proposed that network utilization processes can explain why minorities in structurally equivalent positions do not receive the same advancement benefits as majorities. Consistent with past research, social structures provide opportunities and possibilities for leadership advancement; however, scholars of this perspective have mainly studied opportunity-based factors (Borgatti et al., 2009). We have developed theory on how actors deliberately decide to use their existing ties. Although network position generally predicts the utilization of majorities' existing ties, this may hold to a lesser extent for minorities. Thus, when interpreting research on social networks, it should be kept in mind that these effects are probably more applicable to majorities than to minorities, because network opportunities and network utilization are more closely aligned for majorities than for minorities. Our work creates an opportunity for an empirical investigation of the relative efficaciousness of network position and network utilization for the leadership advancement of minority versus majority actors.

Our framework also offers implications for theory on cognitive social network structures (see Brands, 2013, for a review). Cognitive social structures are individuals' cognitive representations of the social network surrounding them and may or may not resemble the actual social network structure. These subjective perceptions include the way in 

which alters perceive the network and can be influenced by the demographics of actors (Brands \& Kilduff, 2013; Brands, Menges, \& Kilduff, 2015). This work implies that it is important to study differences between minority and majority actors because their perceptions of the content of the social network (i.e., the resources and opportunities available to them; cf. Ibarra, 1995) might differ while perceptions of the structure of the social network remain constant. These perceptual differences between minority and majority actors could lead to differences in network utilization, which in turn has implications for leadership advancement. By investigating cognitive structural representations of networks and the cognitive representations of the resources within these networks, we can advance our understanding of cognitive social structures as an antecedent of agency.

Moreover, we have drawn heavily on research on gender and racial minorities in leadership positions due to a lack of research on other attributes than gender and racegenerally restricted to research on African Americans, Latin Americans, and Asian Americans. Nevertheless, our aim is to provide theory that could be applied to a broad range of minorities. For instance, we not only think of a White male when we think about a leader (Eagly \& Karau, 2002; Rosette et al., 2008), we also infer that he belongs to the majority in other social categories, such as sexual preference, religious background, and disability. From this perspective, social categorization processes can affect all minority social groups-even when effects may be stronger for more easily discernable attributes such as gender and race. Indeed, social categorization processes as well as moderating influences apply to a wide range of attributes (van Knippenberg \& Schippers, 2007).

At the same time, it is important to note that not all minorities will be affected by social categorization processes in the same way. Some social groups' stereotypes overlap more with the leader category than others' (cf. Livingston, Rosette, \& Washington, 2012). Indeed, it seems that the more stereotypical attributes of a social category are associated with 

higher competence, the stronger the association with leadership (cf. Todorov, Mandisodza, Goren, \& Hall, 2005). The extent to which individuals benefit from network utilization is based on the congruity between their social group membership and leadership (for career utilization) and competence (for work utilization). Some social groups are, for instance, associated with stereotypes of high competence (e.g., Asian social groups, Fiske et al., 2002), and therefore, constraints with regard to work utilization in particular may be less prominent for the members of these social groups as compared to other minority groups.

Furthermore, different social category group memberships such as race, gender, class, and sexuality can interact. For instance, stereotypes that are associated with White women are different from stereotypes that are associated with Asian women or Black men; and even within a single social category there might be different sub-categories, each with its own stereotypes associated with them (Rosette, Koval, Ma, \& Livingston, 2016). Investigating the complex interplay of different minority group memberships-i.e., issues of intersectionality (Sanchez-Hucles \& Davis, 2010)—in network utilization processes would offer valuable insights into understanding how belonging to multiple (as compared to one or none) minority groups affects leadership advancement disparities via career and work utilization. For instance, one way in which our theoretical framework might inform research on intersectionality is that belonging to multiple minority groups affects stereotypes of lower competence, and that these stereotypes affect career and work utilization of actors and alters, thereby offering a perspective on why some minority groups, e.g., Black women, are relatively more underrepresented compared to other minority groups, e.g., White women.

Consistent with Ibarra's (1993) assertions regarding the constraints minorities face in building an advantageous network, our research also predicts differential effects of homophilous versus heterophilous ties. In relation to network utilization, it might be easier for actors to engage in network utilization with homophilous rather than with heterophilous 
1

2

others (McPherson, Smith-Lovin, \& Cook, 2001). This is consistent with Ibarra's conceptual argument that cross-gender and cross-race relationships will be weaker and less stable than homophilous ones (Ibarra, 1993: 71, proposition 8). One could also argue that homophilous ties create higher levels of social capital particularly when it comes to the ease of reaching out to a network connection. Yet, if we consider that both Whites and non-Whites endorse Whiteness as a characteristic associated with the leadership stereotype (Gündemir et al., 2014), engaging with similar others can be explained by individual differences in the endorsement of normative fit. Future scholars should explore how network utilization processes might vary across heterophilous versus homophilous ties, especially taking into account that minorities and majorities usually do not have equal levels of social capital (i.e., no structural equivalence).

Our conceptual framework additionally has implications for research on diversity cognition (e.g., diversity beliefs, van Knippenberg, et al., 2007; diversity attitudes, Kossek \& Zonia, 1993; diversity mindsets, van Knippenberg et al., 2013; multicultural [vs. color-blind] beliefs, Plaut, Thomas, \& Goren, 2009) and diversity climates (McKay, Avery, Tonidandel, Morris, Hernandez, \& Hebl, 2007; Mor Barak, Cherin, \& Berkman, 1998). Research on diversity cognition has shown that individuals not only differ in the extent to which they hold (negative) beliefs about social categories (Glick \& Fiske, 1996; McConahay, 1986), but also the extent to which they embrace diversity (Dwertmann, Nishii, \& van Knippenberg, 2016; van Knippenberg, van Ginkel, \& Homan, 2013). Network diversity is likely to shape both actors' and alters' understanding of difference as an asset from which the team or organization can benefit. Hence, the more social categories are viewed as contributing to important work capabilities, the less White and male social categories will be used in pattern matching and pattern completion processes by alters in network utilization. 
Likewise, an organization's diversity climate, which reflects employees' perceptions that an organization adheres to fair personnel practices and the degree to which minority employees are integrated into the work environment (Mor Barak et. al, 1998), is often manifest in both formal practices and explicit behavioral patterns (McKay et al., 2007). Different from diversity cognition, which reflects one's own perspective on diversity, diversity climate reflects one's perception of the organization's perspective on diversity. Favorable diversity climates are understood to be conducive to creating and maintaining a diverse workforce (McKay et al., 2007), and promote the conditions under which such a diverse workforce can thrive (Ely \& Thomas, 2001).

\section{Practical Implications}

Organizational structures, policies, and initiatives can be instrumental in influencing the network utilization of minorities (for a review, see Nishii, Khattab, Shemla, \& Paluch, 2018). Networking programs, for example, could include training in effective networking with a focus on the unique constraints minorities experience when engaging in networking. Such training could focus on the difference between networking for career versus work purposes to provide minorities with insights into why and how to utilize their networks. Additionally, implementing structural changes to increase the representation of minorities, especially in influential managerial positions, could minimize the implications of referrals to demographically similar others. Indeed, role models play an important part in enhancing minorities' motivation and beliefs of self-efficacy when utilizing their networks for career purposes. Minority role models who have successfully moved up the hierarchical ranks could convey the importance of utilizing network ties for career purposes and could remove some of the uneasiness that minorities might feel when engaging in career utilization of network

ties. To create sustainable change, organizations must implement more than a single practice. Moreover, it is important to realize that reducing social category salience by having 
more individuating information about minorities only works when individuals are directly connected to minorities, as that is when individuating information about the actor typically is available. Indirect connections to minorities result in reduced access to individuating information and thus the reliance on social categories is not necessarily reduced. In practice, this means that organizational efforts to increase diversity should not only focus on creating diversity at lower levels, but throughout the organizational hierarchy. If organizations fail to increase diversity throughout their entire hierarchy, minorities' leadership advancement may still stagnate due to social categorization processes in alters' career-supporting activities, such as referrals.

An additional intervention that organizations could implement to mitigate referring brokers' cognitive search limitations is to use explicit language about gender, race, and other minority categories in intra-organizational leadership searches. By encouraging referring brokers to engage in thoughtful deliberation and evaluations of majority and minority actors in searching their network for leadership candidates, the automaticity of their cognitive search based on social category information is disrupted. Although high power actors tend to categorize more quickly, this effect is mitigated when they pay more attention to the individual (Goodwin, Gubin, Fiske, \& Yzerbyt, 2000). Thus, it is similarly important that indirect alters ask referring brokers for individuating information about candidates. Organizations also can improve minorities' leadership advancement outcomes by reducing the importance of career utilization for leadership advancement. Organizations with an up-or-out career structure, for instance, provide a career structure that targets the assumption of interest in leadership advancement. In such a structure, there is less need for individuals to alert their network of their desire to move up the hierarchical ladder because the structure dictates that everybody should be considered for a promotion. As an example, consider the academic tenure track requirement for untenured assistant professors: the 
expectation is that they remain with their employer because they want to attain promotion and tenure. Alternatively, when the structure of the organization is not up-or-out, targeted recruiting tactics such as organizing recruitment days for high potentials at predominantly minority or female institutions of higher education (Avery \& McKay, 2006) can remove minorities' need to communicate their leadership aspirations. Additionally, taking the question (or appropriateness) of one's career ambitions out of the equation helps level the playing field for minorities because it eliminates the need for career utilization to communicate career ambitions.

Structural substitutes for career utilization that target the assumption of interest in leadership advancement do not substitute for actions drawing attention to an individual's qualifications. If promotion decisions hinge on subjective evaluations of qualifications, those who engage in career utilization to advertise their qualifications enhance their chances of leadership advancement. With fewer objective criteria for leadership advancement, objective performance becomes relatively less important, and the support of the network (i.e., career utilization by actors and endorsement by referring brokers) becomes relatively more important for leadership advancement. As such, implementing objective performance criteria is an important additional step that organizations can take to reduce the importance of career utilization for leadership advancement.

\section{CONCLUSION}

Our theory of network utilization underlines the central role of individuals' active and purposeful actions within the structure of their social network. In so doing, we explain how actors and alters can mitigate the psychological barriers associated with using their existing network ties. Notably, our research also sheds light on the role of alters in this process, which we hope is a call to action for those of majority categories to endorse minority actors in both career- and work-based capacities. By no means will social category salience ever disappear 
1

2

3

4

5

6

7

8

9

10

11

12

13

14

15

16

17

18

19

20

21

22

23

24

25

26

27

28

29

30

31

32

33

34

35

36

37

38

39

40

41

42

43

44

45

46

47

48

49

50

51

52

53

54

55

56

57

58

59

60

from the workplace. Yet, over time, as network diversity increases, the agency exerted by both actors and alters alike can produce an ever-equalizing playing field. 


\section{REFERENCES}

Adler, P. S., \& Kwon, S. W. 2002. Social capital: Prospects for a new concept. Academy of Management Review, 27(1): 17-40.

Avery, D. R., \& McKay, P. F. 2006. Target practice: An organizational impression management approach to attracting minority and female job applicants. Personnel

Psychology, 59(1): 157-187.

Baer, M. 2010. The strength-of-weak-ties perspective on creativity: a comprehensive examination and extension. Journal of Applied Psychology, 95(3): 592.

Baker, W. E., \& Obstfeld, D. 1999. Social capital by design: Structures, strategies, and institutional context. In R. T. Leenders and S. M. Gabbay (eds.) Corporate Social Capital and Liability, 89-105. Boston: Kluwer Academic.

Bem, S. L. 1981. Gender schema theory: A cognitive account of sex typing. Psychological Review, 88(4): 354-364.

Bensaou, B. M., Galunic, C., \& Jonczyk-Sédès, C. 2014. Players and purists: Networking strategies and agency of service professionals. Organization Science, 25(1): 29-56.

Berger, J., Rosenholtz, S. J., \& Zelditch, M. 1980. Status organizing processes. Annual Review of Sociology, 479-508.

Bertrand, M., \& Mullainathan, S. 2004. Are Emily and Greg more employable than Lakisha and Jamal? A field experiment on labor market discrimination. American Economic Review, 94(4): 991-1013.

Bian, Y. 1997. Bringing strong ties back in: Indirect ties, network bridges, and job searches in China. American Sociological Review, 366-385.

Blau, P. 1977. Inequality and heterogeneity. New York: Free Press.

Blickle, G., Schneider, P. B., Liu, Y., \& Ferris, G. R. 2011. A Predictive Investigation of 
Applied Social Psychology, 41(12): 3026-3048.

Borgatti, S. P., \& Cross, R. 2003. A relational view of information seeking and learning in social networks. Management Science, 49(4): 432-445.

Borgatti, S. P., \& Foster, P. 2003. The network paradigm in organizational research: A review and typology. Journal of Management, 29: 99-1013.

Borgatti, S. P., Mehra, A., Brass, D. J., \& Labianca, G. 2009. Network analysis in the social sciences. Science, 323: 892-895.

Borman, W. C., \& Motowidlo, S. J. 1997. Task performance and contextual performance: The meaning for personnel selection research. Human Performance, 10(2): 99-109.

Bowler, W.M., Halbesleben, J.R., Stodnick, M., Seevers, M.T., \& Little, L.M.. 2009. The moderating effect of communication network centrality on motive to perform interpersonal citizenship. Journal of Managerial Issues, 21(1):80-96.

Brands, R. A. 2013. Cognitive social structures in social network research: A review. Journal of Organizational Behavior, 34(S1): S82-S103.

Brands, R. A., \& Kilduff, M. 2013. Just like a woman? Effects of gender-biased perceptions of friendship network brokerage on attributions and performance. Organization Science, 25(5): 1530-1548.

Brands, R. A., Menges, J. I., \& Kilduff, M. 2015. The leader-in-social-network schema: Perceptions of network structure affect gendered attributions of charisma. Organization Science, 26(4): 1210-1225.

Brooks, A. W., Gino, F., \& Schweitzer, M. E. 2015. Smart people ask for (my) advice: Seeking advice boosts perceptions of competence. Management Science, 61(6): $1421-1435$.

Burgess, D., \& Borgida, E. 1999. Who women are, who women should be: Descriptive and prescriptive gender stereotyping in sex discrimination. Psychology, Public Policy, 
and Law, 5(3): 665-692.

Burnette, J. L., Pollack, J. M., \& Hoyt, C. L. 2010. Individual differences in implicit theories of leadership ability and self- efficacy: Predicting responses to stereotype threat. Journal of Leadership Studies, 3(4): 46-56.

Burt, R. S. 1992. Structural Holes: The Social Structure of Competition. Cambridge, MA: Harvard University Press.

Burt, R. S. 1997. The contingent value of social capital. Administrative Science Quarterly, 339-365.

Burt, R. S. 1998. The gender of social capital. Rationality and Society, 10(1): 5-46.

Burt, R. S. 2000. The network structure of social capital. Research in Organizational Behavior, 22: 345-423.

Carton, A. M., \& Rosette, A. S. 2011. Explaining bias against Black leaders: Integrating theory on information processing and goal-based stereotyping. Academy of Management Journal, 54(6): 1141-1158.

Chung-Herrera, B. G., \& Lankau, M. J. 2005. Are we there yet? An assessment of fit between stereotypes of minority managers and the successful- manager prototype. Journal of Applied Social Psychology, 35(10): 2029-2056.

Davies, P. G., Spencer, S. J., \& Steele, C. M. 2005. Clearing the air: identity safety moderates the effects of stereotype threat on women's leadership aspirations. Journal of Personality and Social Psychology, 88(2): 276.

Dreher, G. F., \& Cox Jr, T. H. 1996. Race, gender, and opportunity: a study of compensation attainment and the establishment of mentoring relationships. Journal of Applied Psychology, 81(3): 297-308.

Dunbar, R. I. 1992. Neocortex size as a constraint on group size in primates. Journal of Human Evolution, 22(6): 469-493. 
Dwertmann, D. J., Nishii, L. H., \& van Knippenberg, D. 2016. Disentangling the fairness \& discrimination and synergy perspectives on diversity climate: moving the field forward. Journal of Management, 42(5): 1136-1168.

Eagly, A. H., \& Carli, L. L. 2007a. Through the Labyrinth: The Truth about How Women Become Leaders. Boston: Harvard Business Press.

Eagly, A. H., \& Carli, L. L. 2007b. Women and the labyrinth of leadership. Harvard Business Review, 85(9): 62-71.

Eagly, A. H., \& Karau, S. J. 2002. Role congruity theory of prejudice toward female leaders. Psychological Review, 109(3): 573-598.

Eden, D., \& Leviatan, U. 1975. Implicit leadership theory as a determinant of the factor structure underlying supervisory behavior scales. Journal of Applied Psychology, 60 : 736-741.

Ely, R. J., \& Thomas, D. A. 2001. Cultural diversity at work: The effects of diversity perspectives on work group processes and outcomes. Administrative Science Quarterly, 46: 229-273.

Fang, R., Landis, B., Zhang, Z., Anderson, M. H., Shaw, J. D., \& Kilduff, M. 2015. Integrating personality and social networks: A meta-analysis of personality, network position, and work outcomes in organizations. Organization Science, 26(4): 12431260.

Feldman, J. M. 1981. Beyond attribution theory: Cognitive processes in performance appraisal. Journal of Applied Psychology, 66(2): 127.

Feldman, D. C., \& Ng, T. W. 2007. Careers: Mobility, embeddedness, and success. Journal of Management, 33(3): 350-377.

Fiske, S. T., Cuddy, A. J., Glick, P., \& Xu, J. 2002. A model of (often mixed) stereotype content: competence and warmth respectively follow from perceived status and 

competition. Journal of Personality and Social Psychology, 82(6): 878-902.

Fiske, S. T., Lin, M., \& Neuberg, S. L. 1999. The continuum model. In. S. Chaiken \& Y. Trope (Eds.), Dual-process theories in social psychology, 321-254.

Fiske, S. T., \& Neuberg, S. L. 1989. Category-based and individuating processes as a function of information and motivation: Evidence from our laboratory. In D. Bar-Tal, C. F. Graumann, A. W. Kruglanski, \& W. Stroebe (Eds.) Stereotyping and prejudice: Changing conceptions, 83-103. New York: Springer.

Fiske, S. T., \& Neuberg, S. L. 1990. A continum of impression formation, from categorybased to individuating processes: Influences of information and motivation on attention and interpretation. Advances in Experimental Social Psychology, 23: 1-74.

Forret, M. L., \& Dougherty, T. W. 2001. Correlates of networking behavior for managerial and professional employees. Group \& Organization Management, 26(3): 283-311.

Forret, M. L., \& Dougherty, T. W. 2004. Networking behaviors and career outcomes: differences for men and women? Journal of Organizational Behavior, 25(3): 419437.

Foti, R. J., Knee Jr, R. E., \& Backert, R. S. 2008. Multi-level implications of framing leadership perceptions as a dynamic process. The Leadership Quarterly, 19(2): 178194.

Gaucher, D., Friesen, J., \& Kay, A. C. 2011. Evidence that gendered wording in job advertisements exists and sustains gender inequality. Journal of Personality And Social Psychology, 101(1): 109-128.

Gilovich, T., Griffin, D., \& Kahneman, D. 2002. Heuristics and Biases: The Psychology of Intuitive Judgment. Cambridge university press.

Glick, P., \& Fiske, S. T. 1996. The ambivalent sexism inventory: Differentiating hostile and benevolent sexism. Journal of Personality and Social Psychology, 70(3): 491-512. 
Glick, P., Wilk, K., \& Perreault, M. 1995. Images of occupations: Components of gender and status in occupational stereotypes. Sex Roles, 32(9-10): 565-582.

Goldin, C., \& Rouse, C. 2000. Orchestrating impartiality: The impact of" blind" auditions on female musicians. National bureau of economic research. American Economic Review, 90(4): 715-41.

Gonzalez, J. A., \& Denisi, A. S. 2009. Cross- level effects of demography and diversity climate on organizational attachment and firm effectiveness. Journal of Organizational Behavior, 30(1): 21-40.

Goodwin, S. A., Gubin, A., Fiske, S. T., \& Yzerbyt, V. Y. 2000. Power can bias impression processes: Stereotyping subordinates by default and by design. Group Processes \& Intergroup Relations, 3(3): 227-256.

Gottfredson, L. S. 1981. Circumscription and compromise: A developmental theory of occupational aspirations. Journal of Counseling Psychology, 28(6): 545-579.

Gouldner, A. W. 1960. The norm of reciprocity: A preliminary statement. American Sociological Review, 25(2): 161-178.

Granovetter, M. 1992. Problems of Explanation in Economic Sociology. In N. Nohria \& R. G. Eccles (eds.) Networks and Organizations: Structure, Form, and Action. Boston, MA: Harvard Business School Press.

Gulati, R., \& Srivastava, S. B. 2014. Bringing agency back into network research: Constrained agency and network action. Research in the Sociology of Organizations, 40: 73-93.

Gündemir, S., Homan, A. C., de Dreu, C. K. W., \& van Vugt, M. 2014. Think Leader, Think White? Capturing and Weakening an Implicit Pro-White Leadership Bias. PloS one, 9(1): e83915.

Handley, I. M., Brown, E. R., Moss-Racusin, C. A., \& Smith, J. L.(2015. Quality of evidence 
revealing subtle gender biases in science is in the eye of the beholder. Proceedings of the National Academy of Sciences, 112(43): 13201-13206.

Heilman, M. E. 1983. Sex bias in work settings: The lack of fit model. Research in Organizational Behavior, 5: 269-298.

Heilman, M. E. 2001. Description and prescription: How gender stereotypes prevent women's ascent up the organizational ladder. Journal of Social Issues, 57: 657-674.

Hernandez, M., Avery, D. R., Tonidandel, S., Hebl, M. R., Smith, A. N., \& McKay, P. F. 2016. The role of proximal social contexts: Assessing stigma-by-association effects on leader appraisals. Journal of Applied Psychology, 101(1): 68-85.

Ibarra, H. 1993. Personal networks of women and minorities in management: A conceptual framework. Academy of Management Review, 18(1): 56-87.

Ibarra, H. 1995. Race, opportunity, and diversity of social circles in managerial networks. Academy of Management Journal, 38(3): 673-703.

Ibarra, H., Kilduff, M., \& Tsai, W. 2005. Zooming in and out: Connecting individuals and collectivities at the frontiers of organizational network research. Organization Science, 16(4): 359-371.

James, E. H. 2000. Race-related differences in promotions and support: Underlying effects of human and social capital. Organization Science, 11(5): 493-508.

Johnson, K. L., Freeman, J. B., \& Pauker, K. 2012. Race is gendered: How covarying phenotypes and stereotypes bias sex categorization. Journal of Personality and Social Psychology, 102(1): 116-.

Joshi, A., \& Knight, A. P. 2015. Who defers to whom and why? Dual pathways linking demographic differences and dyadic deference to team effectiveness. Academy of Management Journal, 58(1): 59-84.

Joshi, A., Liao, H., \& Jackson, S. E. 2006. Cross-level effects of workplace diversity on sales 
performance and pay. Academy of Management Journal, 49(3): 459-481.

Judd, C. M., \& Park, B. 1993. Definition and assessment of accuracy in social stereotypes. Psychological Review, 100(1): 109-128.

Judge, T. A., Bono, J. E., Ilies, R., \& Gerhardt, M. W. 2002. Personality and leadership: A qualitative and quantitative review. Journal of Applied Psychology, 87: 765-780.

Judge, T. A., Colbert, A. E., \& Ilies, R. 2004. Intelligence and leadership: A quantitative review and test of theoretical propositions. Journal of Applied Psychology, 89: $542-552$.

Kalev, A. 2009. Cracking the glass cages? Restructuring and ascriptive inequality at work. American Journal of Sociology, 114(6): 1591-1643.

Kang, S. K., \& Bodenhausen, G. V. 2015. Multiple identities in social perception and interaction: Challenges and opportunities. Annual Review of Psychology, 66: 547574.

Katz, A. J., \& Williams, M. P. 1997. Gender, self-employment and weak-tie networking through formal organizations. Entrepreneurship \& Regional Development, 9(3): 183-198.

Keller, J., \& Dauenheimer, D. 2003. Stereotype threat in the classroom: Dejection mediates the disrupting threat effect on women's math performance. Personality and Social Psychology Bulletin, 29(3): 371-381.

Kilduff, M., \& Brass, D. J. 2010. Organizational social network research: Core ideas and key debates. Academy of Management Annals, 4(1): 317-357.

Kilduff, M., \& Tsai, W. 2003. Social Networks and Organizations. Sage.

King, E. B., Mendoza, S. A., Madera, J. M., Hebl, M. R., \& Knight, J. L. 2006. What's in a name? A multiracial investigation of the role of occupational stereotypes in selection decisions. Journal of Applied Social Psychology, 36(5): 1145-1159. 
Koenig, A. M., \& Eagly, A. H. 2014. Evidence for the social role theory of stereotype content: Observations of groups' roles shape stereotypes. Journal of Personality and Social Psychology, 107(3): 371-392.

Koenig, A. M., Eagly, A. H., Mitchell, A. A., \& Ristikari, T. 2011. Are leader stereotypes masculine? A meta-analysis of three research paradigms. Psychological bulletin, 137(4): 616-642.

Konrad, A. M., Seidel, M. D. L., Lo, E., Bhardwaj, A., \& Qureshi, I. 2017. Variety, Dissimilarity, and Status Centrality in MBA Networks: Is the Minority or the Majority More Likely to Network Across Diversity? Academy of Management Learning \& Education, 16(3): 349-372.

Kossek, E. E., \& Zonia, S. C. 1993. Assessing diversity climate: A field study of reactions to employer efforts to promote diversity. Journal of Organizational Behavior, 14(1): $61-81$

Klyver, K., \& Foley, D. 2012. Networking and culture in entrepreneurship. Entrepreneurship \& Regional Development, 24(7-8): 561-588.

Kunda, Z., \& Sherman-Williams, B. 1993. Stereotypes and the construal of individuating information. Personality and Social Psychology Bulletin, 19(1): 90-99.

Lanaj, K., \& Hollenbeck, J. 2015. Leadership over-emergence in self-managing teams: The role of gender and countervailing biases. Academy of Management Journal, 58: $1476-1494$.

Lee, F. 1997. When the going gets tough, do the tough ask for help? Help seeking and power motivation in organizations. Organizational behavior and Human Decision Processes, 72(3): 336-363.

Leslie, L. M., Mayer, D. M., \& Kravitz, D. A. 2014. The stigma of affirmative action: a stereotyping-based theory and meta-analytic test of the consequences for 
performance. Academy of Management Journal, 57(4): 964-989.

Leslie, S. J., Cimpian, A., Meyer, M., \& Freeland, E. 2015. Expectations of brilliance underlie gender distributions across academic disciplines. Science, 347(6219): 262265.

Liu, H., \& Baker, C. 2016. White knights: Leadership as the heroicisation of whiteness.

Leadership, 12(4): 420-448.

Livingston, R. W., Rosette, A. S., \& Washington, E. F. 2012. Can an agentic Black woman get ahead? The impact of race and interpersonal dominance on perceptions of female leaders. Psychological Science, 23(4): 354-358.

Lord, R. G., Foti, R. J., \& De Vader, C. L. 1984. A test of leadership categorization theory: Internal structure, information processing, and leadership perceptions. Organizational Behavior and Human Performance, 34(3): 343-378.

Lord, R.G. , Foti, R.J., \& Phillips, J.S. 1982. A theory of leadership categorization. In

J.G. Hunt, U. Sekaran, C. Schriesheim (Eds.), Leadership: Beyond establishment views, 104121. Southern Illinois University, Carbondale.

Lord, R. G., \& Maher, K. J. 1991. Leadership and Information Processing: Linking Perceptions and Performance. Routledge, New York.

Lyness, K. S., \& Heilman, M. E. 2006. When fit is fundamental: performance evaluations and promotions of upper-level female and male managers. Journal of Applied Psychology, 91(4): 777-785.

McConahay, J. B. 1986. Modern racism, ambivalence, and the Modern Racism Scale: Prejudice, discrimination, and racism. In J. F. Dovidio \& S. L. Gaertner (Eds.) Prejudice, Discrimination, And Racism, 91-125. San Diego, CA: Academic Press.

McGuire, G. M. 2002. Gender, race, and the shadow structure a study of informal networks and inequality in a work organization. Gender \& Society, 16(3): 303-322. 
McKay, P. F., Avery, D. R., Tonidandel, S., Morris, M., Hernandez, M., \& Hebl, M. $\quad$ R. (2007). Racial differences in employee retention: Are diversity climate perceptions the key? Personnel Psychology, 60: 35-62.

McPherson, M., Smith-Lovin, L., \& Cook, J. M. 2001. Birds of a feather: Homophily in social networks. Annual Review of Sociology, 27: 415-444.

Meeker, B. F., \& Weitzel-O'Neill, P. A. 1977. Sex roles and interpersonal behavior in taskoriented groups. American Sociological Review, 42(1): 91-105.

Mehra, A., Kilduff, M., \& Brass, D. J. 1998. At the margins: A distinctiveness approach to the social identity and social networks of underrepresented groups. Academy of Management Journal, 41(4): 441-452.

Melamed T. 1996. Career success: An assessment of a gender-specific model. Journal of Occupational and Organizational Psychology, 69: 217-242.

Mendes, W. B., Blascovich, J., Hunter, S. B., Lickel, B., \& Jost, J. T. 2007. Threatened by the unexpected: Physiological responses during social interactions with expectancyviolating partners. Journal of Personality and Social Psychology, 92(4): 698-716.

Metz, I., \& Tharenou, P. 2001. Women's Career Advancement: The Relative Contribution of Human and Social Capital. Group \& Organization Management, 26(3): 312-342.

Mor Barak, M. E., Cherin, D. A., \& Berkman, S. 1998. Organizational and personal dimensions in diversity climate: Ethnic and gender differences in employee perceptions. Journal of Applied Behavioral Science, 34: 82-104.

Morrison, E. W. 2002. Newcomers' relationships: The role of social network ties during socialization. Academy of Management Journal, 45(6): 1149-1160.

Ng, T. W., Eby, L. T., Sorensen, K. L., \& Feldman, D. C. 2005. Predictors of objective and subjective career success: A meta-analysis. Personnel Psychology, 58(2): 367-408.

Nishii, L. H., Khattab, J., Shemla, M., \& Paluch, R. M. In press. A multi-level process model 
for understanding diversity practice effectiveness. Academy of Management Annals.

Nkomo, S. M. 1992. The emperor has no clothes: Rewriting "race in organizations". Academy of Management Review, 17(3): 487-513.

Obstfeld, D. 2005. Social networks, the tertius iungens orientation, and involvement in innovation. Administrative Science Quarterly, 50(1): 100-130.

Ospina, S., \& Foldy, E. 2009. A critical review of race and ethnicity in the leadership literature: Surfacing context, power and the collective dimensions of leadership. The Leadership Quarterly, 20(6): 876-896.

Parks-Stamm, E. J., Heilman, M. E., \& Hearns, K. A. 2008. Motivated to penalize: Women's strategic rejection of successful women. Personality and Social Psychology Bulletin, 34(2): $237-247$.

Paustian-Underdahl, S. C., King, E. B., Rogelberg, S. G., Kulich, C., \& Gentry, W. A. 2017. Perceptions of supervisor support: resolving paradoxical patterns across gender and race. Journal of Occupational and Organizational Psychology, 90(3): 436-457.

Pendry, L. F., Driscoll, D. M., \& Field, S. C. 2007. Diversity training: Putting theory into practice. Journal of Occupational and Organizational Psychology, 80(1): 27-50.

Peters, K., Ryan, M., Haslam, S. A., \& Fernandes, H. 2012. To Belong or Not to Belong. Journal of Personnel Psychology, 11: 148-158.

Pettigrew, T. F., \& Tropp, L. R. 2006. A metaanalytic test of intergroup contact theory. Journal of Personality and Social Psychology, 90: 751-783.

Plaut, V. C., Garnett, F. G., Buffardi, L. E., \& Sanchez-Burks, J. 2011. "What about me?" Perceptions of exclusion and Whites' reactions to multiculturalism. Journal of Personality and Social Psychology, 101(2): 337-353.

Plaut, V. C., Thomas, K. M., \& Goren, M. J. 2009. Is multiculturalism or color blindness better for minorities? Psychological Science, 20(4): 444-446. 
Podolny, J. M., \& Baron, J. N. 1997. Resources and relationships: social networks and mobility in the workplace. American Sociological Review, 62(5): 673-693.

Project Implicit. https://implicit.harvard.edu/implicit/faqs.html\#faq10. Accessed April 25, 2018.

Ridgeway, C. L., \& Smith-Lovin, L. 1999. The gender system and interaction. Annual Review of Sociology, 191-216.

Rosette, A. S., Koval, C. Z., Ma, A., \& Livingston, R. 2016. Race matters for women leaders: Intersectional effects on agentic deficiencies and penalties. Leadership Quarterly, 27(3): 429-455.

Rosette, A. S., Leonardelli, G. J., \& Phillips, K. W. 2008. The White standard: racial bias in leader categorization. Journal of Applied Psychology, 93(4): 758-777.

Rosette, A. S., \& Livingston, R. W. 2012. Failure is not an option for Black women: Effects of organizational performance on leaders with single versus dual-subordinate identities. Journal of Experimental Social Psychology, 48(5): 1162-1167.

Rudman, L. A., \& Phelan, J. E. 2010. The effect of priming gender roles on women's implicit gender beliefs and career aspirations. Social Psychology, 41(3): 192-202.

Sagas, M., \& Cunningham, G. B. 2005. Racial Differences in the Career Success of Assistant Football Coaches: The Role of Discrimination, Human Capital, and Social Capital. Journal of Applied Social Psychology, 35(4): 773-797.

Sanchez-Hucles, J. V., \& Davis, D. D. 2010. Women and women of color in leadership: Complexity, identity, and intersectionality. American Psychologist, 65(3): 171-181.

Schein, V. E. 1973. The relationship between sex role stereotypes and requisite management characteristics. Journal of Applied Psychology, 57: 95-100.

Schein, V. E. 1975. The relationship between sex role stereotypes and requisite management characteristics among female managers. Journal of Applied Psychology, 60: 340-344. 

Schneider, W., \& Shiffrin, R. M. 1977. Controlled and automatic human information processing: I. Detection, search, and attention. Psychological Review, 84(1) : 1-66.

Seibert, S. E., Kraimer, M. L., \& Liden, R. C. 2001. A social capital theory of career success. Academy of Management Journal, 44(2): 219-237.

Sen, M., \& Wasow, O. 2016. Race as a bundle of sticks: Designs that estimate effects of seemingly immutable characteristics. Annual Review of Political Science, 19: 499522.

Shantz, A., Wright, K., \& Latham, G. 2011. Networking with boundary spanners: a quasicase study on why women are less likely to be offered an engineering role. Equality, Diversity and Inclusion, 30(3): 217-232.

Shiffrin, R. M., \& Schneider, W. 1977. Controlled and automatic human information processing: II. Perceptual learning, automatic attending and a general theory. Psychological Review, 84(2): 127-190.

Sidanius, J., \& Pratto, F. 2001. Social Dominance: An Intergroup Theory of Social Hierarchy and Oppression. Chicago: Cambridge University Press.

Singh, V., Kumra, S., \& Vinnicombe, S. 2002. Gender and impression management: Playing the promotion game. Journal of Business Ethics, 37(1): 77-89.

Smith, R. A. 2005. Do the determinants of promotion differ for white men versus women and minorities? An exploration of intersectionalism through sponsored and contest mobility processes. American Behavioral Scientist, 48(9): 1157-1181.

Smith, E. B., Menon, T., \& Thompson, L. 2012. Status differences in the cognitive activation of social networks. Organization Science, 23(1): 67-82.

Sparrowe, R. T., Liden, R. C., Wayne, S. J., \& Kraimer, M. L. 2001. Social networks and the performance of individuals and groups. Academy of Management Journal, 44(2): 316-325. 

Spencer, S. J., Steele, C. M., \& Quinn, D. M. 1999. Stereotype threat and women's math performance. Journal of Experimental Social Psychology, 35(1): 4-28.

Steele, C. M., \& Aronson, J. 1995. Stereotype threat and the intellectual test performance of African Americans. Journal of Personality and Social Psychology, 69(5): 797-811.

Sy, T. 2010. What do you think of followers? Examining the content, structure, and consequences of implicit followership theories. Organizational Behavior and Human Decision Processes, 113(2): 73-84.

Sy, T., Shore, L. M., Strauss, J., Shore, T. H., Tram, S., Whiteley, P., \& Ikeda-Muromachi, K. 2010. Leadership perceptions as a function of race-occupation fit: The case of Asian Americans. Journal of Applied Psychology, 95(5): 902-919.

Tajfel, H., \& Turner, J. C. 1979. An integrative theory of intergroup conflict. In W. G. Austin \& S. Worchel (Eds.) The social psychology of intergroup relations, 33-47. Monterey, CA: Brooks/Cole.

Tessler, R. C., \& Schwartz, S. H. 1972. Help seeking, self-esteem, and achievement motivation: an attributional analysis. Journal of Personality and Social Psychology, 21(3): 318 .

Thatcher, S. M., \& Patel, P. C. 2012. Group faultlines: A review, integration, and guide to future research. Journal of Management, 38(4): 969-1009.

Thomas-Hunt, M. C., \& Phillips, K. W. 2004. When what you know is not enough: Expertise and gender dynamics in task groups. Personality and Social Psychology Bulletin, 30(12): 1585-1598.

Todorov, A., Mandisodza, A. N., Goren, A., \& Hall, C. C. 2005. Inferences of competence from faces predict election outcomes. Science, 308(5728): 1623-1626.

Turner, J. C., Hogg, M. A., Oakes, P. J., Reicher, S. D., \& Wetherell, M. S. 1987. Rediscovering the Social Group: A Self-Categorization Theory. Basil Blackwell. 
US Census Bureau of Labor Statistics, Current Population Survey. 2016. Table 8: Employed people by Detailed Occupation, Race, and Hispanic or Latino Ethnicity, 2015 Annual Averages.

van den Brink, M., \& Benschop, Y. 2014. Gender in Academic Networking: The Role of Gatekeepers in Professorial Recruitment. Journal of Management Studies, 51(3): 460-492.

van Emmerik, I. J. 2006. Gender differences in the creation of different types of social capital: A multilevel study. Social Networks, 28(1): 24-37.

van Knippenberg, D., De Dreu, C. K. W., \& Homan, A. C. 2004. Work group diversity and group performance: an integrative model and research agenda. Journal of Applied Psychology, 89(6): 1008-1022.

van Knippenberg, D., Haslam, S. A., \& Platow, M. J. 2007. Unity through diversity: Valuein-diversity beliefs, work group diversity, and group identification. Group Dynamics, 11(3): 207-222.

van Knippenberg, D., \& Schippers, M. C. 2007. Work group diversity. Annual Review of Psychology, 58: 515-541.

van Knippenberg, D., van Ginkel, W. P., \& Homan, A. C. 2013. Diversity mindsets and the performance of diverse teams. Organizational Behavior and Human Decision Processes, 121(2): 183-193.

Watson, J. 2012. Networking: Gender differences and the association with firm performance. International Small Business Journal, 30(5): 536-558.

Wolfram, H. J., Mohr, G., \& Schyns, B. 2007. Professional respect for female and male leaders: influential gender-relevant factors. Women in Management Review, 22(1): 19-32.

Wolsko, C., Park, B., Judd, C. M., \& Wittenbrink, B. 2000. Framing interethnic ideology: 
effects of multicultural and color-blind perspectives on judgments of groups and individuals. Journal of Personality and Social Psychology, 78(4): 635-654.

Wood, W., \& Karten, S. J. 1986. Sex differences in interaction style as a product of perceived sex differences in competence. Journal of Personality and Social Psychology, 50(2): 341-347.

Zatzick, C. D., Elvira, M. M., \& Cohen, L. E. 2003. When is more better? The effects of racial composition on voluntary turnover. Organization Science, 14(5): 483-496.

Zhou, J., Shin, S. J., Brass, D. J., Choi, J., \& Zhang, Z. X. 2009. Social networks, personal values, and creativity: evidence for curvilinear and interaction effects. Journal of Applied Psychology, 94(6): 1544.

Zweigenhaft, R. L. 2014. Diversity among CEOs and corporate directors: has the heyday come and gone? Who Rules America? http://www2.ucsc.edu/whorulesamerica/power/diversity_among_ceos.html. Accessed December 23, 2014. 

FIGURE 1. CONCEPTUAL MODEL

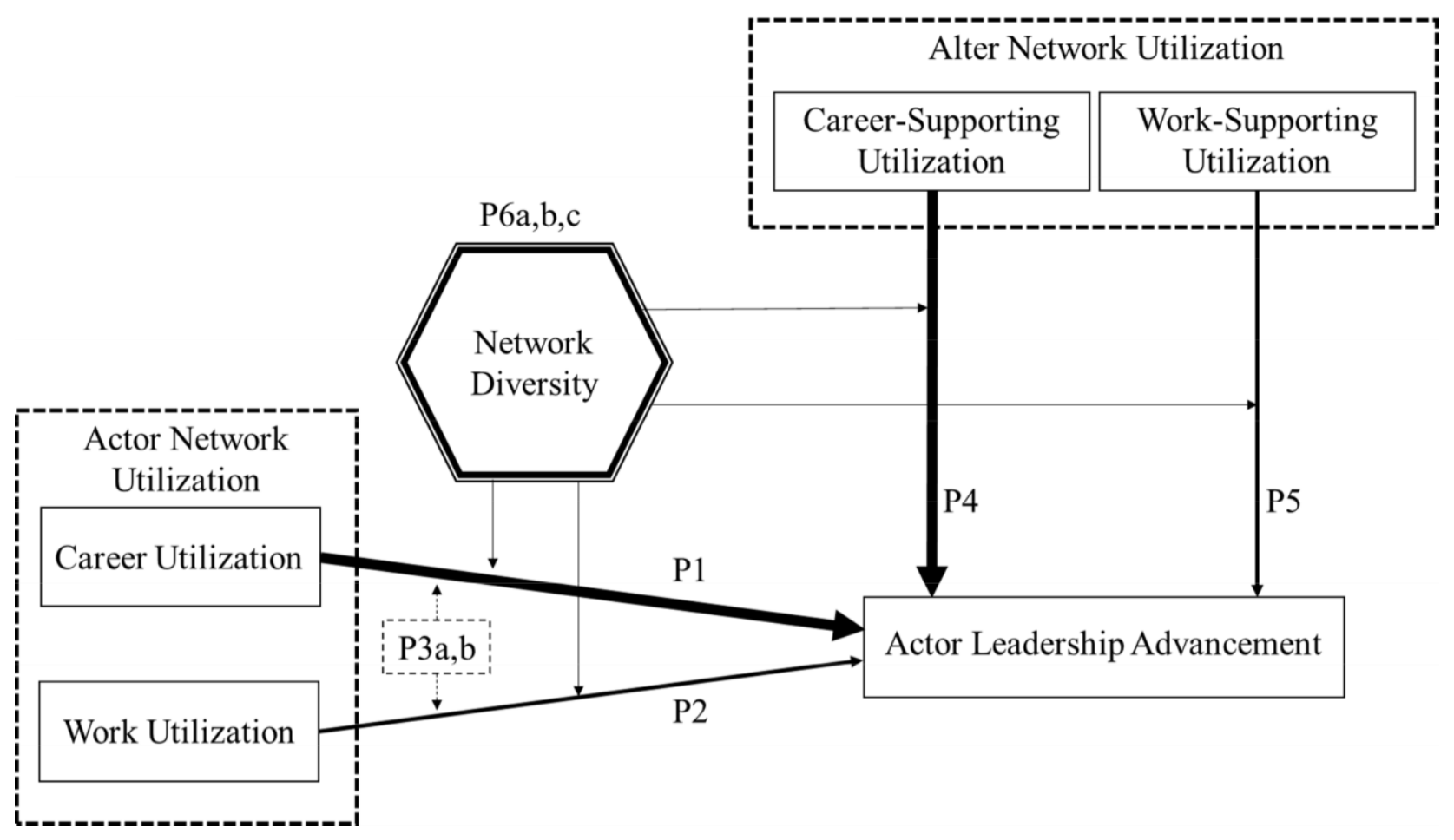


FIGURE 2. CAREER-SUPPORTING UTILIZATION: REFERRAL PROCESS

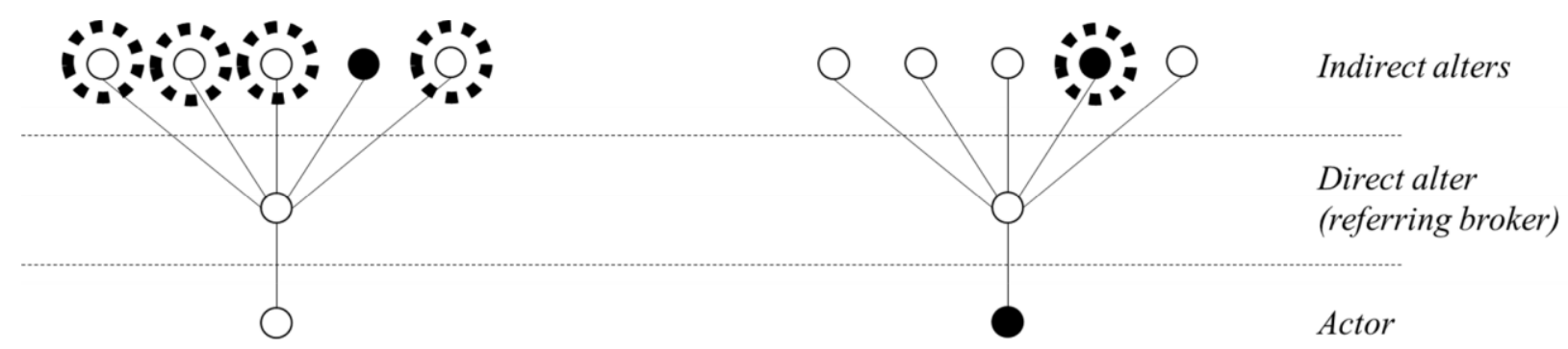

(a) A majority actor is more likely to be connected to majority alters. (b) A minority actor is more likely to be connected to minority alters.
Legend:

Majority member

Minority member 